\title{
Pembelajaran Online dengan Googele Classroom Terhadap Minat Belajar Mahasiswa FKIP UHN
}

\author{
Adi Suarman Situmorang1; Friska B. Siahaan². \\ 1,2 Prodi Pend. Matematika FKIP Universitas HKBP Nommensen Medan \\ adisuarmansitumorang@uhn.ac.id; friskasiahaan@uhn.ac.id
}

\begin{abstract}
Abstrak
Penelitian ini termasuk penelitian jenis eksperimental bersifat quasieksperimen dengan tujuan: 1) Untuk mengetahui kondisi pembelajaran online dengan google classroom terhadap minat belajar mahasiswa prodi pendidikan matematika FKIP UHN. 2) Untuk mengetahui persentase pencapaian minat belajar mahasiswa prodi pendidikan matematika FKIP UHN yang diajarkan dengan pembelajaran online dengan googele classroom. Hasil penelitian menunjukkan bahwa: 1) Dari hasil observasi aktivitas mengajar dosen diperoleh rerata hasil pengamatan sebesar 4,352 yang artinya kemampuan mengajar dosen menggunakan pembelajaran online dengan google classroom "Sangat Baik" dan dari hasil observasi aktivitas aktif mahasiswa juga diperoleh rerata hasil pengamatan sebesar 4,333 yang artinya aktivitas aktif mahasiswa berada pada kategori "Sang Baik". 2) Presentase peningkatan pencapaian minat belajar mahasiswa sebelum dan sesudah pembelajaran pembelajaran online dengan googele classroom untuk masing masingindikator adalah 49,96\% (kategori sangat baik), 50,52\% (kategori sangat baik), 49,74\% (kategori sangat baik), dan 50,74\% (kategori sangat baik). Hal ini menunjukkan bahwa desain model pembelajaran pencapaian konsep sangat baik digunakan untuk meningkatkan minat belajar peserta didik

Kata Kunci: Pembelajaran online, google classroom, Minat Belajar
\end{abstract}

\begin{abstract}
This research is a quasi-experimental research with the following objectives: 1) To determine the conditions of online learning with google classroom on the learning interest of students of the UHN mathematics education study program. 2) To determine the percentage of achievement of student interest in mathematics education study program FKIP UHN who is taught by online learning with googele classroom . The results showed that: 1) From the observation mengaja activity $\mathrm{r}$ lecturer average of observations obtained at 4.352 , which means the ability to teach lecturers use online learning with google classroom is "Very Good" and from the results of observations of active student activities also obtained a mean of 4, 333 observations, which means that active student activities are in the "Good" category. 2) The percentage of increasing student learning interest achievement before and after learning online learning with Googele classroom for each indicator is 49, $96 \%$ (very good category), $50.52 \%$ (very good category), 49, $74 \%$ (very good category). good), and 50.74\%(very good category). This shows that the design of the concept achievement learning model is very well used to increase students' interest in learning

Keywords: Online Learning, Google Classroom, Interest In Learning
\end{abstract}

\section{PENDAHULUAN}

Pendidikan merupakan suatu unsur yang paling penting dalam meningkatkan sumber daya manusia. Melalui pendidikan maka manusia akan dapat menguasai ilmu pengetahuan dan teknologi, meningkatkan sumber daya manusia, dan dapat menyelesaikan permasalahan yang dihadapi (Situmorang Adi S. dan Siahaan Friska, 2019). Pendidikan bertujuan untuk mengembangkan potensi peserta didik agar menjadi manusia yang beriman dan bertaqwa kepada Tuhan Yang Maha Esa, berahlak mulia, sehat, berilmu, cakap, kreatif, mandiri, dan menjadi warga negara yang demokratis serta bertanggung jawab. Hal ini sejalan dengan undang-undang nomor 20 tahun 2003 tentang sistem Pendidikan Nasional bahwa pendidikan nasional berfungsi mengembangkan kemampuan dan membentuk watak serta peradaban 
bangsa yang bermartabat dalam rangka mencedaskan kehidupan bangsa (UU No. 20 Tahun 2003)

Namun kenyataannya banyak masalah yang terdapat didunia pendidikan, khusunya Indonesia. Salah satu masalah yang terjadi didalam dunia pendidikan di Indonesia adalah lemahnya proses pembelajaran ditandai dengan siswa kurang bersemangat atau kurang bergairah dalam proses belajar mengajar atau yang disebut penurunan minat belajar, sehingga mengakibatkan proses berpikir semakin menurun. Kondisi proses berpikir yang semakin menurun akan mengakibatkan proses penyelesaian masalah peserta didik semakin rendah (Sianipar Linda, 2017).

Kondisi penurunan minat belajar peserta didik khususnya untuk mahasiswa hampir sering terjadi untuk setiap angkatan dari mahasiswa yang telah duduk di semester 6 sampai dengan semester 8 dengan menunjukkan ciri-ciri dimana mahasiswa selalu mengalami penurunan minat dan motivasi belajar. Penurunan minat belajar untuk mahasiswa di semester 6 sampai semester 8 ini disebabkan oleh karena metode mengajar yang berpariasi tetapi memiliki bentuk proses belajar mengajar yang sama, tagihan-tagihan belajar yang begitu banyak, serta ketakutan mahasiswa akan masa depan setelah tamat kuliah (Situmorang, 2019).

Kesulitan lain yang dialami mahasiswa adalah banyaknya tenaga pengajar belum mampu merencanakan suatu pembelajaran matematika yang menarik, efektif dan bermakna (Situmorang Adi, 2018). Bahkan sampai saat ini sebagian dosen masih banyak menggunakan paradigma lama dalam mengajar dengan metode ceramah dan mengharapkan siswa duduk, dengar, catat dan hafal. Menurut Wina Sanjaya, metode ceramah dapat diartikan sebagai cara menyajikan pelajaran melalui penuturan lisan atau penjelasan langsung pada sekelompok siswa (Sitorus Parlindungan dkk., 2017).

Kewajiban sebagai pendidik tidak hanya memberikan ilmu tetapi juga dapat mengubah perilaku anak didik, memberikan dorongan yang positif sehingga anak didik termotivasi, memberi suasana belajar yang menyenangkan agar mereka bisa berkembang (Nainggolan Sintong, 2015). Anak didik yang cerdas, bukan saja anak didik yang hasil nilai ulangannya baik, nilai rapornya yang tinggi, tetapi juga emosional dan fungsi motoriknya berjalan dengan baik sehingga tugas pendidik adalah menciptakan iklim belajar dan pembelajaran yang sehat dan menyenangkan, memberikan dorongan kepada anak didiknya agar mempunyai motivasi yang tinggi (Situmorang Adi S., 2013).

Karenanya pendidik harus bisa mendesain pembelajaran sebagai bagian dalam perencanaan mengajarnya, agar anak didikmemiliki minat belajar serta dapat memahami pelajaran yang diberikan oleh pendidik secara seksama. Desain pembelajaran yang dilakukan oleh pendidik mempunyai peranan yang penting dalam keberhasilan pendidikan khususnya dalam meningkatkan minat belajar peserta didik. Minat pribadi memberikan pengertian sebagai suatu ciri pribadi individu yang merupakan disposisi abadi yang relatif stabil. Minat pribadi ini umumnya ditujukan pada suatu kegiatan khusus, misalnya minat khusus pada olahraga, ilmu pengetahuan, musik, tarian, dan komputer. Kebanyakan pemilihan karier seseorang didasarkan pada minat seseorang terhadap berbagai kegiatan dan karier yang disukai dan yang akan ditekuninya. Eccles dan Wigfield mengemukakan mengenai minat intrinsik yang secara konseptual berkaitan sama dengan minat pribadi (Mikarsa Hera Lestari, dkk.,2009). 
Minat situasional merupakan minat yang ditimbuklan oleh kondisi atau faktor-faktor lingkungan. Hidi dan Anderson mengemukakan bahwa minat situasional berbeda dari sekadar keingintahuan seseorang karena minat ini berkaitan dengan sesuatu yang sangat spesifik, dan bukan hanya merupakan gambaran stuktural dari sesuatu hal atau lingkungan atau topik (Mikarsa Hera Lestari, dkk.,2009). Minat situasional ini pun dapat berkembang menjaadi minat pribadi. Misalnya pengalaman seseorang membaca buku mengenai berbagai percobaan fisika, membuatnya lama-lama menjadi tertarik pada fisika.

Minat sering diartikan sebagai suatu kesukaan, kegemaran atau kesenangan seseorang akan sesuatu hal berupa kegiatan atau aktivitas (Sukardi 1988:61). Minat juga diartikan sebagai suatu kondisi yang terjadi apabila sesorang melihat ciri-ciri atau arti sementara situasi yang dihubungkan dengan keinginan-keinginan atau kebutuhan-kebutuhan sendiri (Sardiman, 2007:77). Menurut Bernard, minat timbul tidak secara tiba-tiba atau spontan, melainkan timbul akibat partisipasi, pengalaman, dan kebiasaan pada waktu belajar atau bekerja (Sardiman 2007:76). Jadi jelas bahwa, minat akan selalu terkait dengan persoalan kebutuhan dan keinginan. Dalam kaitannya dengan belajar, Sardiman (2007:1) menyebutkan bahwa minat belajar siswa erat hubungannya dengan kepribadian, motivasi, ekspresi dan konsep diri atau identifikasi, faktor keturunan da pengaruh eksternal atau lingkungan. Dalam praktiknya, minat atau dorongan dalam diri siswa terkait dengan apa dan bagaimana siswa dapat mengaktualisasikan dirinya melalui belajar.

Indikator minat ada empat, yaitu: 1) Perasaan Senang. Seorang siswa yang memiliki perasaan senang atau suka terhadap suatu mata pelajaran, maka siswa tersebut akan terus mempelajari ilmu yang disenanginya. Tidak ada perasaan terpaksa pada siswa untuk mempelajari bidang tersebut. 2) Ketertarikan Siswa. Berhubungan dengan daya gerak yang mendorong untuk cenderung merasa tertarik pada orang, benda, kegiatan atau bisa berupa pengalaman afektif yang dirangsang oleh kegiatan itu sendiri. 3) Perhatian Siswa. Perhatian merupakan konsentrasi atau aktivitas jiwa terhadap pengamatan dan pengertian, dengan mengesampingkan yang lain dari pada itu. Siswa yang memiliki minat pada objek tertentu, dengan sendirinya akan memperhatikan objek tersebut. dan 4) Keterlibatan Siswa. Ketertarikan seseorang akan suatu objek yang mengakibatkan orang tersebut senang dan tertarik untuk melakukan atau mengerjakan kegiatan dari objek tersebut (Safari, 2003).

Pandemi COVID-19 merupakan musibah yang memilukan seluruh penduduk bumi. Seluruh segmen kehidupan manusia di bumi terganggu, tanpa kecuali pendidikan. Banyak negara memutuskan menutup sekolah, perguruan tinggi maupun universitas, termasuk Indonesia. Ada dua dampak bagi keberlangsungan pendidikan yang disebabkan oleh pandemi Covid-19. Pertama adalah dampak jangka pendek, yang dirasakan oleh banyak keluarga di Indonesia baik di kota maupun di desa, dimana banyak keluarga yang kurang familier melakukan sekolah di rumah apalagi yang namanya pembelajaran dengan cara online. Kedua adalah dampak jangka panjang, dimana banyak kelompok masyarakat di Indonesia yang akan terpapar dampak jangka panjang dari covid-19 ini. Dampak pendidikan dari sisi waktu jangka panjang adalah aspek keadilan dan peningkatan ketidaksetaraan antar kelompok masyarakat dan antardaerah di Indonesia.

Salah satu pembelajaran yang trend digunakan di sumatera utara, khususnya di universitas HKBP Nommensen adalah pembelajaran online menggunakan Google Classroom merupakan inovasi dari Google For Educationyang menarik karena merupakan produk yang dibuat untuk mendampingi guru dan siswa dalam melaksanakan kegiatan belajar mengajar. Sehingga membuat google classroom sebagai media dalam pelaksanaan 
pembelajaran karena dapat digunakan siswa belajar diluar waktu pembelajaran yang tidak terbatasi oleh ruang dan waktu (Pradana, 2017).Untuk membantu menjawab pertanyaan penelitian tersebut penulis mendeskripsikan bagaimana penggunaan google classroom dalam pembelajaran dari berbagai artikel di bawah ini.

Dalam Wikipedia dijelaskan bahwa google classroom merupakan suatu model pembelajaran campuran yang diperuntukkan terhadap setiap ruang lingkuppendidikan. Selanjutnya pengertian googleclassroom adalah aplikasi yang berbentuk ruang kelas yang terhubung melalui koneksi internet dan terjadi di dunia maya.Aplikasi googleclassroommemiliki fitur yang mendukung proses pembelajaran e-Learning. Dalam Wikipedia juga dijelaskan bahwa ada beberapa fitur yang ditawarkan google classroom antara lain adanya fitur assignment (pemberian tugas), adanya proses pengukuran (grading) dengan skema penilaian yang berbeda, komunikasi dua arah antara guru dengan siswa yang didukung oleh google drive, adanya fitur arsip program dan fitur aplikasi google classroom dapat diakses dengan perangkat android dan iOS. Kesemua fitur tersebut tersedia di googleclassroomdan dapat digunakan oleh guru selama proses pembelajaran (Iskandar dkk, 2020).

Penelitian yang dilakukan oleh Sabran \& Edy Sabara (2019) dengan judul "Keefektifan Google Classroom Sebagai Media Pembelajaran". Menurut Smaldino et al. (2008) teknologi dan media sangat berperan banyak dalam proses belajar mengajar jika dalam pengajarannya masih berpusat pada guru maka teknologi dan media ini dapat digunakan dalam mendukung dalam penyajian dan pengajaran lalu dapat dilihat dari sisi lain jika pengajaran tersebut berpusat pada peserta didik maka peserta didik merupakan pengguna utama dalam teknologi dan media tersebut. Sabran (2019) elearningdapat dimanfaatkan dalam meningkatkan pemahaman materi dan memperluas segala sumber dari beberapa sumber materi ajar maupun dapat menambah aktivitas belajar peserta didik dan serta merta membantu guru dalam mengefisienkan waktu pembelajaran di kelas. Metode penelitian ini merupakan penelitian eksperimen dengan tahapan pengembangan yang menghasilkan suatu pembelajaran e learningdengan menggunakan google classroomyang dinilai berdasarkan kriteria kualitas model, kepraktisan dan keefektifan.

\section{METODE PENELITIAN}

Penelitian ini dilaksanakan di Fakultas Keguruan dan Ilmu Pendidikan Universitas HKBP Nommensen. Adapun waktu pelaksanaan penelitian ini adalah semester genap tahun pelajaran 2018/2019. Populasi dalam penelitian ini adalah seluruh mahamahasiswa program studi pendidikan matematika FKIP UHN Medan. Sampel yang dipergunakan dalam penelitian ini adalah satu kelas mahasiswa prodi pendidikan matematika FKIP UHN yang mengikuti mata kuliah Metode Numerik, yang terdiri dari 6 kelas dengan pengambilan sapel dengan teknik random sampling.

Penelitian ini termasuk penelitian jenis eksperimental bersifat quasieksperimen yang bertujuan: 1) Untuk memperoleh sebuah desain pembelajaran online dengan googele classroom yang diperoleh untuk dapat meningkatkan minat belajar mahasiswa prodi pendidikan matematika FKIP UHN 2) Untuk mengetahui peningkatan minat belajar mahasiswa prodi pendidikan matematika FKIP UHN yang diajarkan dengan pembelajaran online dengan googele classroom. 
Penelitian ini melibatkan satu kelas yang diajarkan dengan model pembelajaran contextual teaching and learning terhadap kemampuan pemahaman konsep matematis mahasiswa prodi pendidikan matematika FKIP UHN. Rancangan penelitian yang digunakan adalah One- shot case study adalah sekolompok sampel dikenai perlakuan tertentu (variabel bebas) kemudian dilakukan pengukuran terhadap variabel tersebut. Desain penelitian ini dapat digambarkan sebagai berikut:

Keterangan :

Tabel 1. Tabel One- shot case study

\begin{tabular}{lccc}
\hline Kelompok & Angket-1 & Treatment & Angket-2 \\
\hline Eksperimen & $\mathrm{O}_{1}$ & $\mathrm{X}$ & $\mathrm{O}_{2}$ \\
\hline
\end{tabular}

$\mathrm{X}=$ perlakuan dengan pembelajaran online dengan googele classroom

$\mathrm{O}=$ Angket Minat belajar.

Sebagai upaya untuk mendapatkan data dan informasi yang lengkap mengenai hal-hal yang ingin dikaji melalui penelitian ini, maka dibuatlah seperangkat instrumen. Instrumen yang akan digunakan pada penelitian ini adalah: 1) Lembar observasi. Lembar observasi pengamatan yang dilakukan untuk mengamati keseluruhan aktivitas yang terjadi selama proses pembelajaran berlangsung. Faktor-faktor yang diamati adalah hal-hal yang berkaitan dengan pelaksanaan model pembelajaran pencapaian konsep yaitu kemampuan guru mengajar menggunakan model pembelajaran yang ditinjau dari kesesuaian materi dengan model, penyampaian materi, komunikasi guru dengan siswa. 2) Angket Minat. Angket minat belajar yang didesain berdasarkan indikator minat belajar. Angket minat belajar berisikan serentetan pertanyaan yang digunakan untuk mengukur bagaimana kondisi minat belajar mahasiswa sebelum perlakuan dan setelah perlakuan. Adapun kriteria pertanyaan untuk mengukur minat belajar yang akan ditanyakan adalah seperti berikut.

Tabel 2 Pedoman pembuatan angket minat belajar.

\begin{tabular}{|c|c|}
\hline Indikator Minat & Kriteria Pertz"yaan \\
\hline \multirow{4}{*}{ Perasaan senang } & Semangat belajar \\
\hline & Kesadaran ingin belajar \\
\hline & Keseriusan belajar \\
\hline & Kemauan belajar \\
\hline \multirow{3}{*}{ Ketertarikan belajar } & Ketertarikan pada pengajar \\
\hline & Ketertarikan pada mata pelajaran \\
\hline & Ketertarikan situasi belajar \\
\hline \multirow{3}{*}{ Perhatian belajar } & Konsentrasibelajar \\
\hline & Kenyamanan belajar \\
\hline & Hasrat belajar \\
\hline \multirow{2}{*}{ Keterlibatan belajar } & Frekuensi belajar \\
\hline & Pemanfa atan waktu belajar \\
\hline
\end{tabular}

Teknik analisis data yang digunakan dalam penelitian ini adalah teknik analisis data deskriptif. Adapun yang akan dideskripsikan dalam penelitian ini adalah: 1) Desain model pembelajaran yang digunakan untuk meningkatkan minat belajar mahasiswa prodi pendidikan matematika FKIP UHN. Lembar observasi yang dilakukan bertujuan untuk mengetahui apakah proses pembelajaran sudah sesuai dengan fase dan langkah-langkah yang dimiliki oleh pembelajaran online dengan googele classroom. 2) Pencapaian minat belajar mahasiswa prodi pendidikan matematika FKIP UHN sebelum pembelajaran dan sesudah proses pembelajaran menggunakan pembelajaran online dengan googele classroom. Data yang digunakan untuk mengetahui pencapaian minat ini adalah data hasil angket minat belajar yang dirancang sesuai dengan indikator minat belajar. Data yang diperoleh akan 
diakumulasikan dan selanjutnya dicari persentase untuk setiap indikator yang berada pada kategori baik dan sangat baik, selanjutnya nilai persentase angket sebelum pembelajaran dan sesudah pembelajaran dibandingkan.

\section{HASIL PENELITIAN DAN PEMBAHASAN}

Untuk mengetahui apakah penelitian telah dilaksanakan dengan baik sesuai dengan langkah-langkah pembelajaran online dengan googele classroom, maka dilakukanlah observasi terhadap aktivitas mengajar dosen dan mahasiswa. Dari hasil analisis diperoleh bahwa aktivitas mengajar dosen telah sesuai dengan pembelajaran online dengan googele classroom karena total rerata hasil pengamatan dari observer pada semua aspek dan indikator model adalah 4,352 yang artinya kemampuan mengajar guru menggunakan pembelajaran online dengan googele classroom "Sangat Baik" dan dari tabel 4.3 terlihat bahwa aktivitas aktif mahasiswa juga telah sesuai dengan la ngkah pembelajaran online dengan googele classroom yang telah dirancang karena nilai rerata aktivitas aktif siswa dari hasil observasi adalah 4,333 yang artinya aktivitas aktif mahsiswa berada pada kategori "Sang Baik".

Untuk melihat pencapaian minat ini adalah data hasil angket minat belajar yang dirancang sesuai dengan indikator minat belajar. Data yang diperoleh akan diakumulasikan dan selanjutnya dicari persentase untuk setiap indikator yang berada pada kategori baik dan sangat baik, selanjutnya nilai persentase angket sebelum pembelajaran dan sesudah pembelajaran dibandingkan. Selanjutnya presentase pencapaian minat yang diperoleh dapat dilihat seperti pada tabel 3. berikut.

Tabel 3 Persentasi Pencapaian Minat Belajar Peserta Didik

\begin{tabular}{lcccc}
\hline \multicolumn{1}{c}{ Indikator } & \multicolumn{2}{c}{ Persentase Pencapaian } & $\begin{array}{c}\text { Persentase } \\
\text { Sebelum (\%) }\end{array}$ & Sesudah (\%) \\
Peningkatan & \\
\hline Perasaan senang & 38,28 & 88,24 & 49,96 & Sangat Baik \\
\hline Ketertarikan belajar & 37,5 & 88,02 & 50,52 & Sangat Baik \\
\hline Perhatian belajar & 38,28 & 88,02 & 49,74 & Sangat Baik \\
\hline Keterlibatan belajar & 37,5 & 88,24 & 50,74 & Sangat Baik \\
\hline
\end{tabular}

Dari tabel 3 di atas terlihat bahwa hasil angket presentase pencapaian minat belajar mahasiswa sebelum pembelajaran untuk masing masing-indikator adalah 38,28 (kategori rendah), 37,5 (kategori rendah), 38,28 (kategori rendah), dan 37,5 (kategori rendah). Hasil angket presentase pencapaian minat belajar mahasiswa sebelum pembelajaran untuk masing masing-indikator adalah 88,24 (kategori sangat tinggi), 88,02 (kategori sangat tinggi), 88,02 (kategori sangat tinggi), dan 88,24 (kategori sangat tinggi). Dengan kata lain dapat dikatakan bahwa presentase peningkatan pencapaian minat belajar mahasiswa sebelum dan sesudah pembelajaran pembelajaran online dengan googele classroom untuk masing masingindikator adalah 49,96\% (kategori sangat baik), 50,52\% (kategori sangat baik), 49,74\% (kategori sangat baik), dan 50,74\% (kategori sangat baik). Hal ini menunjukkan bahwa Pembelajaran online dengan google classroom sangat baik digunakan untuk meningkatkan minat belajar peserta didik khususnya minat belajar mahasiswa FKIP UHN.

\section{SIMPULAN DAN SARAN}

Sesuai dengan tujuan penelitian dan berdasarkan hasil penelitian dapat disimpulkan bahwa: 1) Dari hasil observasi aktivitas mengajan dosen diperoleh hasil pengamatan yang menyatakan bahwa kemampuan mengajar guru dan aktivitas aktif siswa "Sangat Baik". 2) Hasil angket presentase pencapaian minat belajar mahasiswa sebelum pembelajaran online 
dengan googele classroom menunjukkan bahwa desain model pembelajaran pencapaian konsep sangat baik digunakan untuk meningkatkan minat belajar peserta didik.

Karena hasil yang diperoleh dalam penelitian ini hanya melihat peningkatan minat belajar mahasiswa dari nilai persentase jumlah angket mahasiswa yang jawannya $\geq 4$ (bersifat deskiptif), maka disarankan: 1) Kepada peneliti selanjutnya untuk menganalisis besarnya peningkatan dengan teknik analisi inferensial. 2) Mengembangkan teknik pengumpulan data agar jangan hanya menggunakan angket saja tetapi perlu dibuat teknik pengumpulan data dari lembar observasi dan wawancara. 3) Perlu ditinjau kembali kekurangan dari desain model pembelajaran pencapaian kosep yang telah dirancang tersebut.

\section{DAFTAR PUSTAKA}

Iskandar, A., \& dkk. (2020). Aplikasi Pembelajaran Berbasis TIK.Yayasan Kita Menulis.

Mikarsa, Hera Lestari dkk.2009. PendidikanAnak di SD. Universitas Terbuka. Jakarta

Nainggolan, Sintong. 2015. Upaya Meningkatkan Reativitas Berpikir Matematis Melalui Model Pembelajaran Pencapaian Konsep Pada Siswa Kelas VII SMP Negeri 1 Bilah Barat. Medan: JSP 2(1):(65-76). https://jsp.uhn.ac.id

Pradana, Diemas Bagas Panca \& Harimurti Rina. (2017). Pengaruh Penerapan Tools Google Classroom pada Model Pembelajaran Project Based Learning terhadap Hasil Belajar Siswa. Jurnal IT-Edu.Vol 02 No.01, 59-67

Sabran, \& Sabara, E. (2019). Keefektifan Google Classroom Sebagai Media Pembelajaran. OJS UNM.

Safari, 2003. Indikator Minat Belajar. Jakarta: Rineka Cipta

Sardiman, 2007, Interaksi dan Motivasi Belajar Mengajar: Bandung, Rajawali Pers

Sianipar, Linda. 2017. Model Pembelajaran Problem Based Learning Terhadap Aktivitas Dan Hasil Belajar Mahasiswa. Medan: JSP 4(2):(50-62). https://jsp.uhn.ac.id

Sitorus Parlindungan. 2017. Pengaruh Model Pembelajaran Inquiry Training Terhadap Hasil Belajar Siswa Pada Materi Pokok Listrik Dinamis Di Kelas X SMA Swasta Parulian 1 Medan: JSP 4(2):(82-91). https://jsp.uhn.ac.id

Situmorang, Adi S. 2013. Desain Model Pencapaian Konsep Terhadap Minat Belajar Mahasiswa FKIP UHN. Medan: Jurnal Penelitian bidang Pendidikan 29(1):(52-59). https://jurnal.unimed.ac.id/2012/index.php/penelitian/issue/archive

Situmorang, Adi S. 2018. Desain Model Pembelajaran Creative Problem Solving Terhadap Kemampuan Pemahaman Konsep Mahasiswa FKIP UHN. Medan: Jurnal Penelitian bidang Pendidikan 24(2):(52-59).

Situmorang, Adi S. 2019. Peningkatan Kemampuan Pemahaman dan Kreativitas Matematis Siswa dengan Menggunakan Pembelajaran online dengan googele classroom. Medan: Jurnal Penelitian bidang Pendidikan 25(1):(55-61).

Smaldino, E. Sharon dkk. (2008). Instructional Technology and Media for Learning. Upper Saddle River, New Jersey Columbus, Ohio. Ninth Edition.

Sukardi Dewa Ketut, 1988, BimbingandanKonseling, Jakarta: Bina Aksara

Sukardi Dewa Ketut, 2002, PengantarPelaksanaan Program Bimbingan dan Konseling di Sekolah, Jakarta: Rineka Cipta

Undang-Undang Republik Indonesia No. 20 Tahun 2003, Sistem Pendidikan Nasional, Bandung: Citra Umbara. 